ISSN: 2146-3042

DOI: $10.25095 / \mathrm{mufad} .510452$

\title{
Otel İşletmelerinde Kârlılığı Etkileyen Değişkenlerin DuPont Analiz Tekniğiyle Ölçülmesi: Avrupa Borsalarında Ekonometrik Bir Analiz
}

\author{
Erdinç KARADENIZ* \\ Levent KOŞAN ${ }^{* *}$ \\ Fatih GÜNAY*** \\ Selda DALAK ${ }^{* * * *}$
}

\section{$\ddot{O Z Z E T}$}

Bu çalıșmanın amacı Avrupa kıtasındaki sermaye piyasalarında işlem gören otel ișletmelerinde kârlılığın DuPont finansal analiz tekniğiyle incelenmesidir. Ayrıca DuPont analiz tekniğinde kullanılan değişkenler bağlamında otel işletmelerinin aktif ve özkaynak karlılıkların etkileyen değişkenler belirlenmeye çalışılmıştır. Bu amaçlarla DuPont tekniğinde ele alınan oranlardan hareketle Avrupa kıtasında payları borsada işlem gören 76 otel işletmesinin 2007-2016 dönemi aktif ve özkaynak kârlılıkları panel veri yöntemiyle analiz edilmiştir. Çalışmada elde edilen sonuçlara göre Avrupa'da halka açık otel işletmelerinin aktif kârlılıkları üzerinde net kâr marjının etkisi pozitif ve anlaml iken, aktif devir hızının anlamlı bir etkisinin olmadığ saptanmıştır. Öte yandan Avrupa'da halka açık otel ișletmelerinde özkaynak kârlılığında net kâr marjının etkisi pozitif yönde anlamlı olup, özkaynak çarpanının etkisi anlamlı ve negatiftir. Aktif kârlıllğında olduğu gibi özkaynak kârlıllğında da aktif devir hızının kârlılık üzerinde anlamlı bir etkiye sahip olmadığı belirlenmiștir. Calıșma sonucunda ayrıca Avrupa'da halka açık otel işletmelerinin incelenen dönemde gider ve maliyetlerini karşllayacak düzeyde bir gelir ve kâr elde edemediği belirlenmiştir. Borsalart.

Anahtar Kelimeler: DuPont Analiz Tekniği, Aktif Kârlılı̆̆ı, Özkaynak Kârlılı̆̆ı, Halka Açık Otel İşletmeleri, Avrupa

JEL Sinıflandırması: G30, G32, L83, Z33.

\section{Measuring Variables Affecting Profitability by Using DuPont Analysis Technique in} Hotel Companies: An Econometric Analysis in European Stock Exchanges

\section{ABSTRACT}

The purpose of this study is to examine the profitability of hotel companies traded on capital markets in European continent by using DuPont financial analysis technique. Besides, variables were tried to be determined that affect the return on asset and return on equity of the hotel companies in the context of variables used in the DuPont analysis technique. For these purposes, the ratios used to determine return on asset and return on equity in the DuPont technique were analyzed of the 76 hotel companies, whose shares traded on stock exchange in European continent, 2007-2016 period by panel data method. According to the results obtained in the study, the effect of net profit margin on the return on asset is positive and significant but the effect of asset turnover is not significant on return on asset of the publicly traded hotel companies in Europe. On the other hand, the effect of net profit margin on return on equity is significant and positive, and the effect of equity multiplier is significant and negative of the publicly traded hotel companies in Europe. It has been determined that the asset turnover does not have any significant effect on return on equity, as in return on asset. As a result of the study, it was determined that publicly traded hotel companies in Europe could not earn income and profits to meet expenses and costs in the examined period.

Keywords: DuPont Analysis Technique, Return on Asset, Return on Equity, Publicly Traded Hotel Companies, European Stock Exchanges.

Jel Classification: G30, G32, L83, Z33.

Makale Gönderim Tarihi: 10.04.2018

Makale Kabul Tarihi: 24.12.2018

\footnotetext{
* Doç. Dr., Mersin Üniversitesi, Turizm Fakültesi, drekaradeniz@ gmail.com, ORCID ID: 0000-0003-2658-8490

** Doç. Dr., Mersin Üniversitesi, Turizm Fakültesi, leventosan @ gmail.com, ORCID ID: 0000-0001-7630-6354

*** Sorumlu Yazar Arş. Gör., Mersin Üniversitesi, Turizm Fakültesi, fgunay@ mersin.edu.tr, ORCID ID: 00000003-0892-514X

**** Arş. Gör., Mersin Üniversitesi, Turizm Fakültesi, selda.khl@ gmail.com, ORCID ID: 0000-0003-2735-1006
} 


\section{GíRiș}

Günümüzde turizm sektöründe faaliyet gösteren işletmeler ülke ekonomilerine yapmış oldukları katkılar nedeniyle önemli bir yere sahiptirler. Bu bağlamda turizm sektöründeki finans yöneticileri işletme kârını ve kârlılıklarını firma değerini artırmaya yönelik olarak analiz ederek tedbirler almalıdır. $\mathrm{Bu}$ açıdan bakıldı̆̆ında firma değerinin maksimize edilmesinde son derece önemli olan kâr ve kârlılığın etkin bir şekilde sağlanması ve sürdürülebilirliğinin gerçekleştirilmesi için kâr ve kârlllığın sürekli analiz edilmesi önem arz etmektedir. Finans literatürüne bakıldığında işletmelerde kârlılık performansının analizinde sıklıkla kullanılan yöntemlerden birisi "DuPont Finansal Analiz" yöntemidir. DuPont analizi, 1920 yılında DuPont Şirketi tarafindan ortaya konulan bir performans ölçüm yöntemidir (Kim, 2016: 53). Dupont analiz tekniği, işletmelerin elde ettikleri kârları detaylı biçimde incelemeye dayanan, diğer ifadeyle işletmenin net kâr marjı, aktif devir hızı ve finansal kaldıracın bir göstergesi olan özkaynak çarpanı olarak üç temel göstergeden ilgili olanların birlikte ele alınarak aktif ve özsermaye kârlılık performansının incelendiği analiz tekniğidir. $\mathrm{Bu}$ göstergeler yatırımcılara işletmenin durumu hakkında hızlıca bilgi veren temel göstergelerdir (Botika, 2012: 1179). DuPont analizi, aktif kârlılı̆ıının belirleyicileri olan net kâr marjı ve aktif devir hızı bileşenlerine derin bir bakış açısı sağlamaktadır (Bauman, 2014: 191). Bu bağlamda DuPont analiz tekniğinin finansal analiz aracı olarak tercih edilmesi işletmelerde aktif kârlılığının, net kâr marjı ve aktif devir hızı, özkaynak kârlılı̆ının ise net kâr marjı, aktif devir hızı ve özkaynak çarpanı ölçümünden etkilenmesine dayanmaktadır.

Otel işletmeleri gerek yatırım gerekse işletme aşamasında sermaye yoğun özelliktedir (Karadeniz vd., 2009: 595). Otel işletmeleri sabit varlık ağırlıklı bir yapıya sahiptir. Turizm talebinde yaşanan hızlı ve ani değişimler, sektördeki rekabetin artması, zevk ve tercihlerdeki değişim ile teknolojik gelişmelerin sektör üzerindeki etkileri gibi nedenlerle faaliyet döneminde yenileme gibi yatırım kararı ile karşı karşıya kalabilmektedir (Karadeniz vd., 2016: 39). Otel işletmeleri yatırımlarında yüksek tutarlı arsa ve bina kiralama, satın alma ve inşas1 nedeniyle sabit maliyet yüküne sahiptir (Guilding, 2002: 196). Yoğun olarak sabit varlığa sahip olması nedeniyle otel işletmelerinde uzun vadeli yabancı kaynak ve özkaynak payının yüksek olması beklenmektedir (Karadeniz vd., 2009: 595). Otel işletmelerinin sahip olduğu bu özellikler nedeniyle işletme yöneticilerinin işletme kâr ve kârlılıklarını doğru bir şekilde analiz ederek firma değerine olumlu etki edecek şekilde kararlarında kullanmaları gerekmektedir.

$\mathrm{Bu}$ çalı̧̧manın amacı Avrupa kıtasındaki sermaye piyasalarında işlem gören otel işletmelerinde kârlılığın DuPont finansal analiz tekniğiyle incelenmesidir. Ayrıca çalışma kapsamında DuPont analiz tekniğinde kullanılan değişkenler bağlamında otel işletmelerinin aktif ve özkaynak kârlılıklarını etkileyen değişkenler belirlenmeye çalışılmıştır. Bu amaçlar kapsamında çalışmada, payları Avrupa borsalarında işlem gören 76 işletmenin 2007-2016 dönemini kapsayan verileri üzerinde 760 gözlem elde edilerek regresyon analizi gerçekleştirilmiştir. Çalışma, belirlenen amaçlar doğrultusunda beş bölümden oluşmaktadır. Giriş bölümünde konuyla ilgili kısa bir bilgiye yer verildikten sonra, çalışmanın birinci bölümünde kısaca DuPont analiz tekniği anlatılmıştır. İkinci bölümde geçmiş çalışmaların kısaca özetlendiği literatür taramasına yer verilmiştir. Üçüncü bölümde çalışma yöntemine ilişkin bilgiler yer almakta olup, dördüncü bölümde bulgulara yer verilmiştir. Çalışmanın beşinci ve son bölümünde ise sonuç ve önerilere yer verilmiştir. 


\section{DUPONT FINANSAL ANALİZ TEKNIĞGi}

DuPont analizinde; işletmelerin aktif kârlılığının hesaplanmasında kullanılan net kâr marjı ve aktif devir hızı ile özkaynak kârlılığının hesaplanmasında aktif kârlılığı değişkenlerine ilave olarak özkaynak çarpanının kullanımıyla özkaynak kârlılık oranına ulaşılmaktadır. Aynı zamanda ayrıştırma yaklaşımı olarak adlandırılan DuPont tekniğine yönelik üç bileşenli DuPont üçgeni Botika (2012: 1180) tarafından Şekil 1'deki gibi ifade edilmektedir.

Şekil 1. Üç Bileşenli DuPont Üçgeni

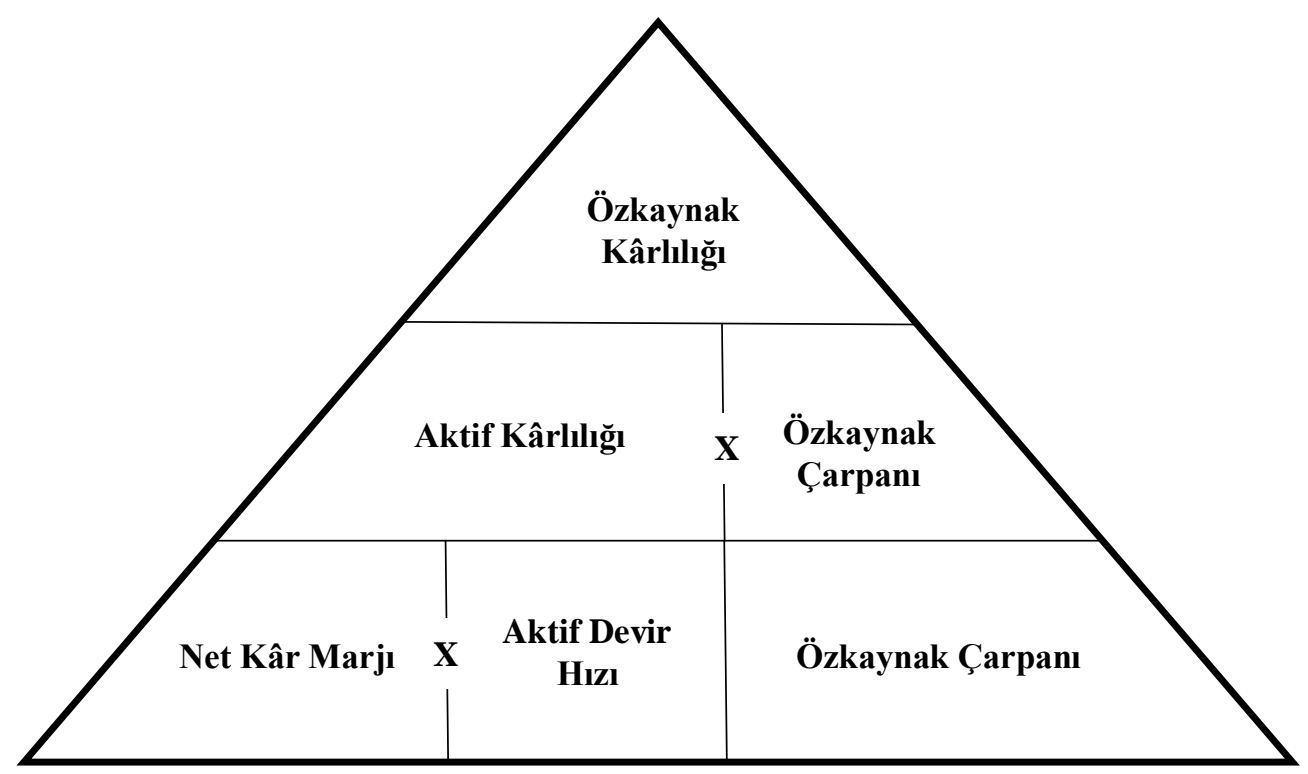

Kaynak: Botika, 2012: 1180

İşletmeler hedeflenen kâr tutarını sağlayabilmek için, net kâr marjı ile aktif devir hızını göz önünde bulundurmak durumundadır (Karapınar ve Ayıkoğlu Zaif, 2013: 262). Aktif kârlılığının DuPont tekniği ile hesaplanmasına ilişkin eşitlik 1 numaralı formülde yer almaktadır.

$$
\text { Aktif Kârlılı̆̆ } l=\frac{\text { Net Kầr }}{\text { Net Satı̧̧lar }} x \frac{\text { Net Satı̧̆lar }}{\text { Toplam Varlık }}
$$

Yapılan bu analiz ilk olarak DuPont firmasında uygulandığından DuPont analizi olarak anılmaktadır (Karapınar ve Ayıkoğlu Zaif, 2013: 262). Buradan hareketle işletmenin yabancı kaynak ve özkaynak yapısını ortaya koyan özkaynak çarpanı ile aktif kârlılı̆̆ çarpıldığında özkaynak kârlılığı elde edilir. DuPont tekniğine göre özkaynak kârlılığına ilişsin eşitlik denklem 2'deki şekildedir.

$$
\text { Özkaynak Kârlılı̆̆ } l=\frac{\text { Net Kầr }}{\text { Net Satı̧̆lar }} x \frac{\text { Net Satı̧̧lar }}{\text { Toplam Varlıklar }} x \frac{\text { Toplam Varlıklar }}{\text { Özkaynaklar }}
$$

DuPont analiz yöntemine göre işletmelerde yabancı kaynak kullanımının artması, finansal kaldıracı artıracak bu da özkaynak kârlılığını artıracaktır (Karapınar ve Ayıkoğlu Zaif, 2013: 263). DuPont yönteminde özkaynak kârlılığının hesaplanmasında kullanılan 
eşitliğin ilk iki çarpanı aktif kârlılığını vermektedir. En sağdaki değişken ise özkaynak çarpanıdır. Sonuç olarak özkaynak kârlılığı, net kâr marjiyla ölçülen satış kârlılığına, aktif devir hızıyla ölçülen aktiflerin kullanım etkinliğine ve özkaynak çarpanıyla ölçülen kaldıraç oranına bağlidır (Koşan ve Karadeniz, 2014: 79). DuPont tekniğindeki formülden hareketle özkaynak kârlılı̆̆ıyla ilgili eşitlik incelendiğinde aktiflerin kullanım etkinliğinin düşük olması, özkaynak kârlılı̆ıını düşürecektir. Ayrıca diğer şartlar sabitken işletme daha fazla kaldıraçtan yararlanarak özkaynak kârlılı̆ını arttırabilir. Ancak işletmenin daha fazla borç kullanımı ile özkaynak kârlılı̆ını arttırabilmesi için aktif kârlılığının borç maliyetinden yüksek olması gerekir (Aydın vd., 2007: 112).

Özkaynak kârlılığında, sermaye yapısı içinde borcun oranı arttığı ölçüde özkaynak kârlılı̆̆ da artacaktır. Negatif bir kârlılık (zarar) söz konusu olduğunda ise, borç oranı arttıkça zarar da o oranda artacaktır. DuPont tekniğinin üstün yönü, tekniğin satış kârlılı̆ını, etkinlik ve finansal kaldıraç gibi üç ayrı noktayı bir arada ele almasıdır. Satı̧ kârlılığı, etkinlik ve finansal kaldıraç finansal analizin önemli bir bölümünü oluşturmaktadır. Tekniğin zayıf yanı ise, ele alınan muhasebe verileriyle işletmenin başarısı ve beklenen nakit akışlarının riski, zamanlanması ve büyüklüğü arasında doğrudan bir bağlantının kurulmasını sağlamamasıdır (Aydın vd., 2007: 112).

\section{LITERATÜR TARAMASI}

Finans alanında işletmelerde kârllılı performansının incelenmesi önem arz eden konuların başındadır. DuPont analizinin kullanıldığ çalışmalar incelendiğinde, işletmelerde aktif ve özkaynak kârlılığının detaylı olarak incelendiği, kârlılığa etki eden kalemlerin ayrıntılı olarak incelendiği ve kârllık üzerine etkilerinin ele alındığ 1 görülmektedir. Tarafımızca yapılan literatür taraması sonucunda ulaşılabilen çalışmalar aşağıda kısaca özetlenmeye çalışılmaktadır.

Karadeniz ve İskenderoğlu (2012), halka açık turizm işletmelerinde aktif kârlılığını etkileyen değişkenleri incelemişlerdir. Çalı̧̧ada İstanbul Menkul Kıymetler Borsası'nda işlem gören sekiz turizm işletmesinin 2009-2012 yılları arasındaki çeyrek dönemlik verileri üzerinde regresyon analizi gerçekleştirilmiştir. Elde edilen sonuca göre aktif kârlılı̆̆ üzerinde kaldıraç oranının negatif yönde, ölçek, pazar payı, net işletme sermayesi devir hızı ve aktif devir hızının pozitif yönde etkili olduğu saptanmışırı. Alacak devir hızı ile stok devir hızının ise aktif kârlıllğı üzerinde etkisinin anlamsız olduğu sonucu elde edilmiştir.

Sheela ve Karthikeyan (2012), Hindistan ilaç endüstrisinde faaliyet gösteren 3 büyük işletme 2003-2012 dönemi finansal performansı DuPont analiz tekniğine göre incelenmiştir. İşletmelerin aktif, özkaynak ve yatırım kârlılığı açısından incelendiği çalışmada en iyi performansa sahip işletmenin maliyet ve giderlerini azaltmaya yoğunlaştığı belirlenmiş̧tir.

Koşan ve Karadeniz (2013) Türk imalat sektörünün finansal performansını DuPont analiz tekniğine göre değerlendirmişlerdir. Çalışmada büyük ölçekli işletmelerin 2009-2011 döneminde aktif devir hızı, net kâr marjı, aktif kârlılığı ve özkaynak kârlılı̆̆ı açısından daha başarılı performans sergiledikleri saptanmıştır. Küçük ölçekli işletmelerde ise aktif kullanımının verimsiz olduğu tespit edilmiştir. Elde edilen sonuca göre finansal performansın ölçek büyüklüğüyle doğru orantılı olduğu belirlenmiştir. 
Bauman (2014), çalışmasında işletmelerde DuPont analiz tekniği bağlamında aktif kârlılığı üzerinde aktif devir hızı ve kâr marjının etkilerini regresyon analizi ile incelemiştir. Elde edilen sonuca göre şirketlerin aktif kârlılığı üzerinde mevcut kâr marjının etkisinin anlamlı olduğu saptanmıştır.

Karaman vd. (2014) çalışmalarında, tarımsal kalkınma kooperatifinin kârlılığını DuPont analizi ile incelemişlerdir. Sonuç olarak kooperatifin aktif karlılığının 0,23, özsermaye karlılığının 0,33 olduğu saptanmış olup, kooperatifin iyi bir yatırım yaptığı ve giderlerini sıkı bir şekilde kontrol altında tuttuğu ortaya konmuştur.

Koşan ve Karadeniz (2014) çalışmalarında konaklama ve yiyecek hizmetleri sektörünün finansal performansını DuPont analiz tekniğini kullanarak incelemişlerdir. İncelenen alt sektörün 2010 ve 2012 döneminde satış kârlılığı, aktif kârlılığı ve özkaynak kârlılıkları pozitif olarak saptanmışken, 2011 yılında tüm göstergelerde negatif kârlılık saptanmıştır. Çalışmada sektörün maliyet ve giderlerinin yüksek olduğu, aktif devir hızının istenen düzeyde olmadığı ve sektörün aktif yatırımlarını yoğun olarak yabancı kaynakla finanse etmesi nedeniyle finansal riskinin yüksek olduğu belirlenmiştir.

Turner vd. (2015), ABD'de faaliyet gösteren hastane işletmelerinin kârlılıklarını DuPont analiz tekniği ile inceledikleri çalş̧mada, 3255 hastane işletmesinin 2007-2012 dönemi verilerini kullanarak regresyon analizi yapmışlardır. Çalışmada özel hastanelerin daha yüksek kâr marjı ve etkinliğe sahip olduğunu ve daha yüksek kaldıraç kullandıklarını saptamışlardır. Kamu hastanelerinin ise yüksek özkaynak kârlılı̆̆ı, kâr marjı ve etkinliğe sahip olmakla birlikte daha düşük kaldıraca sahip olduğu görülmüştür.

Doğan ve Topal (2016), çalışmalarında payları Borsa İstanbul'da işlem gören 136 imalat işletmesinin 2005-2012 yılları verileri üzerinde kârlılığı belirleyen finansal faktörleri tespit etmeyi amaçlamışlardır. Panel veri analizi sonucunda işletme toplam varlıklarının aktif ve özsermaye kârlılıkları ile pozitif, kaldıraç oranının aktif ve özsermaye kârlılıkları ile negatif yönde anlamlı ilişskinin bulunduğunu tespit etmişlerdir. Çalışmada ele alınan cari oran ve firma yaşı ile kârlılık değişkenleri arasında anlamlı bir ilişki tespit edilememiştir.

Kim (2016) yaptığı çalışmada, yiyecek dağıtım işletmelerinin kârlılıklarını DuPont analiz tekniğiyle incelemeyi amaçlamıştır. Bu amaçla 2013-2015 dönemini kapsayan 3 yıllık aktif ve özkaynak kârlılıkları ile net kâr marjı, aktif devir hızı ve özkaynak çarpanı ile seçilmiş diğer oranların korelasyon analizi ile ilişkisini incelemiştir. Çalışma bulgularında aktif ve özkaynak kârlılıklarının her ikisiyle de net kâr marjının pozitif yüksek korelasyonlu ve anlamlı olduğu saptanmıştır. Diğer yandan aktif devir hızı ile özkaynak çarpanı oranlarının kârlılık ile ilişkisi anlamlı olmamakla birlikte sırasıyla pozitif ve negatif işarete sahip olduğu gözlenmiştir.

Warrad ve Nassar (2017), yapmış oldukları çalışmada, Ürdün sanayi sektörünün 20082015 dönemi kârlılıklarını DuPont analiz tekniğiyle incelemişlerdir. İşletmelerin özkaynak karlılığı üzerinde kâr marjı, aktif devir hızı ve özkaynak çarpanının etkisini regresyon analizi ile analiz etmişlerdir. Elde edilen sonuca göre işletmelerin özkaynak kârlılığı üzerinde, kâr marjı ve aktif devir hızının pozitif yönde anlamlı, buna karşın finansal kaldıraç ile istatistiki açıdan anlamlı bir ilişkisinin olmadığı saptanmıştır. 


\section{VERİ VE YÖNTEM}

$\mathrm{Bu}$ çalışmada otel işletmelerinde DuPont analiz tekniği kapsamında ele alınan oranların aktif ve özkaynak kârlılıklarına etkilerinin panel veri yöntemiyle incelenmesi amaçlanmıştır. Avrupa borsalarında işlem gören otel işletmelerinin 2007-2016 dönemine ait finansal tabloları Mersin Üniversitesi Bilimsel Araştırma Proje Birimi tarafından desteklenen 2017-2-TP3-2655 kodlu proje kapsamında Thomson Reuters EIKON veri tabanından elde edilerek, DuPont analiz tekniği bağlamında aktif ve özsermaye kârlılığının belirlenmesinde kullanılan oranlar hesaplanmıştır. Çalışmada 10 yılın seçilmesindeki sebep işletmelerin kârlılıklarındaki durumlarının geniş bir periyodu dikkate alarak incelenmesinin amaçlanmış olmasidir.

Halka açık otel işletmelerinin DuPont analiz tekniği kapsamında ele alınan oranların kârlılık üzerine etkilerinin incelenmesinin amaçlandığ 1 bu çalışmada Thomson Reuters EIKON veri tabanında yer alan Avrupa borsalarında iş tanımında otel geçen toplam 141 işletme bulunmakta olup, 2007-2016 döneminde verileri bulunan işletme sayısı 85'dir. Tüm yıllarda veya herhangi bir yıl satışlar kalemi eksik ya da negatif özkaynağa sahip olan işletmeler hesaplama hatasına neden olabileceğinden araştırma kapsamına dâhil edilmemişstir. $\mathrm{Bu}$ doğrultuda toplam 76 işletme verisi üzerinde analiz gerçekleştirilmiştir.

Analize dâhil edilen 76 halka açık otel işletmesinin ülkelere göre dağılımı Tablo 1'de yer almaktadır. Tablo 1 incelendiğinde toplam 21 ülkeden çeşitli sayılarda işletme bulunurken, en fazla verisine ulaşılabilen işletmenin bulunduğu ülkeler Hırvatistan, Kıbrıs ve Bulgaristan'dır.

Tablo 1. Analize Dâhil Edilen İşletmelerin Ülkelere Göre Dağılımı ve İşletme Sayıları

\begin{tabular}{|r|r|r|r|r|r|}
\hline \multicolumn{1}{|c|}{ Ülke } & Isşletme Sayısı & \multicolumn{1}{|c|}{ Ülke } & \multicolumn{1}{|c|}{ İșletme Sayısı } & \multicolumn{1}{|c|}{ Ülke } & \multicolumn{1}{|c|}{ Issletme Sayısı } \\
\hline Hırvatistan & 14 & Makedonya & 3 & Avusturya & 1 \\
\hline Kıbris & 10 & Slovenya & 3 & Bosna Hersek & 1 \\
\hline Bulgaristan & 7 & Estonya & 2 & Finlandiya & 1 \\
\hline Fransa & 6 & İspanya & 2 & Hollanda & 1 \\
\hline İngiltere & 6 & Polonya & 2 & İsviçre & 1 \\
\hline Türkiye & 6 & Portekiz & 2 & Malta & 1 \\
\hline Romanya & 5 & Almanya & 1 & Yunanistan & $\mathbf{7 6}$ \\
\hline Toplam
\end{tabular}

Çalışmanın amacı doğrultusunda DuPont analiz tekniğinde ele alınan net kâr marjı $(\mathrm{NKM})$ ve aktif devir hızı (ADH) oranlarının aktif kârlılığına (AK), net kâr marjı, aktif devir hızı ve özkaynak çarpanının (ÖKÇ) özkaynak kârlılığına (ÖKK) etkilerinin belirlenebilmesi amaciyla panel veri regresyon analizi yöntemiyle analizler gerçekleştirilmiştir. Panel veriler daha büyük boyutta örneklemle çalışma imkânı, zaman serisi ve yatay kesitte gözlenemeyen etkilerin belirlenmesi, daha detaylı bilgi edinilmesi ve daha etkin bilgi elde edilmesi gibi nedenlerle (Wooldridge, 2002; Baltagi, 2005; Kaplan, 2016) tercih edilmektedir. Bu kapsamda bu çalışmada payları Avrupa borsalarında işlem gören otel işletmelerinin 20072016 dönemini kapsayan 10 y1llık verisi üzerinde 760 gözlem ile panel veri analizleri gerçekleştirilmiştir. DuPont analiz tekniği bağlamında aktif kârlılığının belirlenmesinde kullanılan oranların etkilerinin belirlenmesi amaciyla kurulan regresyon denklemi Model I'deki gibidir. 


$$
A K_{t}=\alpha+\beta_{1} * N K M_{t}+\beta_{2} * A D H_{t+} e_{t}
$$

Model I'de yer alan bağımlı değişken AK, aktif kârlılığını ifade etmektedir. Diğer yandan bağımsız değişkenlerden NKM net kâr marjını, ADH ise aktif devir hızını ifade etmektedir. Modelde yer alan $\alpha$ terimi bağımlı değişkenin sabit terimini ifade etmektedir. Modelde yer alan e ise hata terimini ifade etmekte olup, açıklanamayan etkileri ifade etmektedir. DuPont analiz tekniği bağlamında özkaynak kârlılı̆̆ının belirlenmesinde kullanılan oranların etkilerinin belirlenmesi amacıyla kurulan regresyon denklemi ise Model II'deki gibidir.

$$
\ddot{O} K K_{t}=\alpha+\beta_{1} * N K M_{t}+\beta_{2} * A D H_{t}+\beta_{3} * \ddot{O} K C_{t+} e_{t}
$$

Özkaynak kârlılığının DuPont tekniği ile hesaplanmasında kullanılan oranların etkilerinin saptanmasına yönelik kurulan Model II'de ÖKK bağımlı değişken olup özkaynak kârlılığını ifade etmektedir. Özkaynak kârlılığına etkilerinin inceleneceği bağımsız değişkenlerden NKM net kâr marjını, ADH aktif devir hızını, ÖKÇ ise özkaynak çarpanını ifade etmektedir.

Zaman serilerinde istatistiksel analiz öncesi serilerin birim kök içerip içermediği yani durağanlığının incelenmesi gerekmektedir. Serilerin durağan olması istenen bir durum olup, durağan olmayan serilerde yapılan analizlerde, sahte regresyon denilen yanıltıcı sonuçlar görülmekte ve geleneksel t, F ve $\mathrm{R}^{2}$ değerleri sapmalı sonuçlar verebilmektedir (Yerdelen Tatoğlu, 2013a: 199). Değişkenlerin birim kök sorunu içermemesi sonrasında tahmin edilecek modellerin testi için panel veri analiz yöntemine karar verilmesi gerekmektedir. Panel verilerde regresyon analizinde kullanılan klasik yöntem, tesadüfi etkiler ve sabit etkiler yöntemi olarak çeşitli tahmin yöntemleri bulunmaktadır. Hem sabit hem de eğim parametrelerinin zamana göre değişmediği modellere klasik modeller denmektedir. Sabit etkiler modelinde eğim parametreleri $(\beta)$ tüm yatay kesitler için aynı iken, sabit parametre $(\alpha)$ birim etki içermesi sebebiyle birimden birime değişmektedir. Örneklerin rastgele seçilmesi ve bunun sonucu olarak birimler arası farklilıkların tesadüfi olması nedeniyle bu birim farklılıklarına tesadüfi etkiler denilmektedir (Yerdelen Tatoğlu, 2013 b: 40, 79-80, 103-104). Panel veri analiz yöntemlerinin seçiminde kimi varsayımlar ve temeller olmakla birlikte, veri seti büyük bir ana kütleden tesadüfi olarak seçilmemişse sabit etkiler yöntemini kullanmak daha doğru olabilmektedir (Yerdelen Tatoğlu, 2013b: 79).

Bu bağlamda panel veri analiz yöntemlerinden klasik model ile sabit etkili ve tesadüfi etkili modellerden hangisinin kullanılacağına karar verilerek uygun yöntemin seçilmesi amacıyla kurulan I ve II numaralı modellere F testi ve olabilirlik oranı testleri uygulanmıştır. F testinde verinin birimlere göre farklılık gösterip göstermediği test edilmekte ve veri birimlere göre farkl1lık göstermiyorsa klasik modelin seçilmesi gerekmektedir. Verinin birimlere göre farklılık göstermediğine karar vermek için $\mathrm{F}$ testinde $\mathrm{H}_{0}$ hipotezi reddedilmelidir. Diğer yandan klasik model ile tesadüfi etkili model arasında karar vermek için olabilirlik oranı testi yapılmaktadır. Yapılan testte $\mathrm{H}_{0}$ hipotezi reddedildiğinde birim etkilerin varlığından söz edilip klasik modelin uygun olmadığına karar verilmektedir (Yerdelen Tatoğlu, 2013b: 165-169). Sabit etki ile tesadüfi etki tahmincileri arasında karar vermek üzere Hausman testi kullanılabilmektedir (Yerdelen Tatoğlu, 2013b: 179). Birim etkiler ile bağımsız değişkenler arasında korelasyon bulunmuyorsa, tesadüfi etkiler modeli geçerlidir (etkindir). Sabit etkiler ile tesadüfi etkiler tahmincileri arasında seçim yapmada 
kullanılan Hausman testinin temel hipotezi tesadüfi etkiler tahmincisinin geçerli olduğu şeklindedir (Hausman, 1978: 1269; Yerdelen Tatoğlu, 2013b: 180).

Bu kapsamda bu çalışmada uygun model tahminci seçimi üzerine testler yapılarak uygun yöntem seçilmiştir. Sonrasında uygun olan yöntemin varsayımları (heteroskedasite, otokorelasyon ve birimler arası korelasyon) test edilmiştir. Elde edilen sonuçlara göre tutarlı sonuçların elde edilmesinde etkili olan varsayımları sağlamaması nedeniyle dirençli tahminler üreten Driscall-Kraay ve Arellano-Froot-Rogers (Yerdelen Tatoğlu, 2013b) yöntemleriyle modeller tahmin edilmiştir.

\section{BULGULAR}

Çalışma amacı doğrultusunda Thomson Reuters EIKON veri tabanından elde edilen finansal tablolardan her bir yıla ait değerler elde edilmiştir. Analiz kapsamındaki 76 otel işletmesinin verileri 10 yıllık panel veri şeklinde düzenlenmiş ve gerçekleştirilen toplam 760 gözleme ilişkin ham değer ve oranlara ilişkin özet istatistikler Tablo 2'de sunulmuştur.

Tablo 2. Verilere İlişkin Özet İstatistikler

\begin{tabular}{|c|c|c|c|c|c|}
\hline Değişken & $\mathbf{N}$ & Ortalama & Minimum & Maksimum & Std. Sapma \\
\hline Net Kâr (Bin \$) & 760 & $38,902.56$ & $-768,517.0$ & $4,767,433.0$ & $287,817.6$ \\
\hline Satışlar (Bin \$) & 760 & $462,154.40$ & 44.9 & $16,400,000.0$ & $1,939,326.0$ \\
\hline Toplam Varlık (Bin \$) & 760 & $1,101,044.00$ & 259.9 & $40,100,000.0$ & $4,561,897.0$ \\
\hline 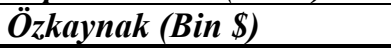 & 760 & $562,685.80$ & 252.1 & $24,600,000.0$ & $2,651,043.0$ \\
\hline Net Kâr Marjı (NKM) & 760 & -0.1068257 & -27.42323 & 11.51515 & 1.65364 \\
\hline Aftif Devir Hozı (ADH) & 760 & 0.3255961 & 0.0015382 & 2.546282 & 0.3106992 \\
\hline$\ddot{O}$ zkaynak Çarpanı (ÖKÇ) & 760 & 2.056145 & 1.005033 & 56.58565 & 2.313027 \\
\hline Aktif Kârlılı̆̆ı (AK) & 760 & 0.0114789 & -1.29028 & 0.515844 & 0.080129 \\
\hline Özkaynak Kârlılı̆̆l (ÖKK) & 760 & -0.0021727 & -8.208378 & 0.9764096 & 0.3462504 \\
\hline
\end{tabular}

Gözlemlere ilişkin özet istatistikler incelendiğinde işletmelerin ortalama net kâr tutarı 38 milyon dolar dolaylarında olup satışların ortalaması 462 milyon dolar dolaylarındadır. Toplam varlık ortalama tutarları 1 milyar 100 milyon dolar dolaylarında iken özkaynak ortalamaları 560 milyon dolar dolaylarındadır. İşletmelerin NKM ortalaması yaklaşık \%-11 olup buna göre incelenen işletmelerin ortalama olarak negatif kâr marjına sahip olduğu belirlenmiştir. İşletmelerde NKM minimum -27 maksimum 11 dolaylarında gerçekleşmiştir. NKM'nin minimum -27 olması ilgili gözlemin gerçekleştiği işletmede yapılan satışların 27 katı zarar edildiğini ifade etmektedir. ADH'nin ortalama yaklaşık 0.33 dolaylarında olması aktiflerin satışların üç katı dolaylarında olduğunu ifade etmektedir. İncelenen işletmelerin ortalama özkaynak çarpanının 2.05 olduğu Tablo 2'de görülmektedir. Bu sonuç, ortalamada işletmelerin borç ağırlıklı bir sermaye yapısına sahip olduğunu ifade etmektedir. Ayrıca maksimum ÖKÇ 56 dolaylarında olup, bu durum ilgili orana sahip işletmenin çok yüksek düzeyde borç kullandığını ifade etmektedir. Ortalama AK \%1 dolaylarında iken işletmelerin aktiflerine karşın elde ettikleri net kârın düşük olduğunu ayrıca standart sapma değerinin 0,08 olması işletmelerin değişkenliklerinin düşük olduğunu ortaya koymaktadır. İşletmelerin ortalama özkaynak kârlılıkları \%-0.2 olup yatırılan özkaynağa karşı zarar ettikleri görülmektedir. Standart sapma açısından ilgili değişkenler ele alındığında ADH, AK ve ÖKK açısından işletmeler önemli ölçüde bir değişkenlik göstermeyip genellikle ortalama değerin etrafında değerlere sahipken, özellikle ÖKÇ'de daha yüksek olmakla birlikte işletmelerin 
NKM ve ÖKÇ değerlerinde değişkenlik daha yüksektir. Buna göre işletmeler NKM ve ÖKÇ açısından daha değişken değerlere sahiptir. Çalışmada analiz edilecek seriler arasındaki ilişkilerin yönünü gösteren korelasyon matrisi Tablo 3'te yer almaktadır.

Tablo 3. Korelasyon Matrisi

\begin{tabular}{|l|l|l|l|l|l|}
\hline Değişken & $\boldsymbol{N K M}$ & $\boldsymbol{A D H}$ & $\ddot{\boldsymbol{O} K C}$ & $\boldsymbol{A K}$ & $\ddot{\boldsymbol{O} K K}$ \\
\hline $\boldsymbol{N K \boldsymbol { M }}$ & 1.0000 & & & & \\
\hline $\boldsymbol{A D H}$ & 0.0902 & 1.0000 & & & \\
\hline$\ddot{\boldsymbol{O} K \boldsymbol{C}}$ & -0.0973 & -0.0169 & 1.0000 & & \\
\hline $\boldsymbol{A K}$ & 0.5523 & 0.1887 & -0.1393 & 1.0000 & \\
\hline$\ddot{\boldsymbol{O} K K}$ & 0.2998 & 0.1153 & -0.8481 & 0.4562 & 1.0000 \\
\hline
\end{tabular}

Korelasyon matrisi, değişkenlerin birbiriyle ilişkisinin yönü ve gücü konusunda fikir vermekte; fakat meydana gelecek bir birimlik değişim karşısında değişkenlerde ne kadarlık bir değişim olacağı konusunda bilgi vermemektedir. Korelasyon matrisinin yer aldığ 1 Tablo 3 incelendiğinde, NKM ve ADH'nin aktif kârlılığ1 ve özkaynak kârlılığı ile pozitif, ÖKÇ'nin ise aktif kârlılığı ve özkaynak kârlılığı ile negatif ilişkili olduğu görülmektedir. NKM ile AK pozitif orta düzeyde ilişkili olup iki değişken arasındaki korelasyon katsayısı 0.5523 'tür. Bu sonuç otel işletmelerinde NKM değişkenindeki artışın AK'de artışa neden olacağını ortaya koymaktadır. ADH ile AK yine pozitif çok zayıf ilişkili ve katsayı 0.1887 'dir. Diğer yandan NKM ile ÖKK pozitif yönde zayıf ilişkili olup katsayı 0.2998, ADH ile ÖKK yine pozitif çok zayıf ilişkili olup katsayı 0.1153 'tür. ÖKÇ ile ÖKK ise negatif yönde yüksek düzeyli ilişkili olup -0.8481'lik bir korelasyon katsayısına sahiptir.

DuPont analiz tekniğine göre pozitif net kâr marjının durumunda özkaynak çarpanının yüksek olması özkaynak kârlılığını artıran bir unsurdur. Ancak net kâr marjının negatif olması durumu ve bu değerin azalması nedeniyle özkaynak çarpanının arttığı oranda özkaynak kârlılığının azalmasına neden olacaktır. Pozitif NKM durumunda ÖKÇ'nın artması işletme sermaye yapısında özkaynağın payı azalırken ve özkaynak kârlılığının artmasına neden olacaktır. Bu bağlamda DuPont analiz tekniğine göre pozitif NKM durumunda ÖKÇ ile ÖKK'nin doğrusal bir ilişki içinde olması beklenmektedir. Ancak DuPont tekniğinde negatif NKM durumunda, ÖKÇ’nin artması özkaynağa karşın elde edilecek zararın artmasına neden olacak ve sonuç olarak ters yönlü bir ilişki gözlenecektir.

Avrupa borsalarında işlem gören otel işletmelerinde AK ve ÖKK üzerinde DuPont tekniğinde kullanılan oranların etkilerinin incelenmesinin amaçlandığı bu çalışmada test edilen modellerde kullanılan değişkenlere ilişkin seriler birim kök analizine tabi tutulmuştur. Panel veri analizlerinde serilerin durağan olması ve birim kök içermemesi istenen bir durumdur (Yerdelen Tatoğlu, 2013a: 199). Durağan olmayan verilerle çalışıldığında yapılan testler güvenilirliğini yitirecektir. Bu kapsamda değişkenlerin durağanlık testlerine ilişkin sonuçlar Tablo 4'te yer almaktadır. 
Tablo 4. Panel Birim Kök Test Sonuçları

\begin{tabular}{|c|c|c|c|}
\hline \multirow{2}{*}{$\begin{array}{ll}\text { Değișken } & \text { Yöntem } \\
\end{array}$} & \multicolumn{3}{|c|}{ Harris-Tzavalis (N: 76, T: 10, K: 760) } \\
\hline & $\rho$ istatistiğ & z değeri & Olasilık (p-value) \\
\hline$N K M$ & -0.0256 & -23.8118 & 0.000 \\
\hline$A D H$ & 0.3817 & -10.9297 & 0.000 \\
\hline$\ddot{O} K C ̧$ & 0.4809 & -7.7932 & 0.000 \\
\hline$A K$ & 0.0315 & -22.0033 & 0.000 \\
\hline$\ddot{O ̈ K K}$ & 0.2381 & -15.4708 & 0.000 \\
\hline & $\mathrm{H}_{0}$ : Paneller bil & mektedir. & \\
\hline
\end{tabular}

Serilerde durağanlığın test edildiği Harris-Tzavalis (1999) birim kök testi küçük zaman büyük yatay kesit panel verilerinde uygun olan bir testtir (Harris-Tzavalis, 1999: 203). Harris-Tzavalis testi sonuçlarına göre (p: 0.000) değişkenlerin birim kök içermediği ve durağan olduğu saptanmıştır.

Aktif kârlılığ 1 ve özkaynak kârlılığında oranların etkilerinin test edildiği modellerde analiz yönteminin seçimine ilişkin yapılan F testi, olabilirlik oranı ve Hausman test sonuçları ise Tablo 5'te gösterilmektedir.

Tablo 5. Model Test Seçimi İçin Yapılan Test Sonuçları

\begin{tabular}{|l|c|r|r|}
\hline Model & \multicolumn{1}{|c|}{ F Testi } & Olabilirlik Oranı & \multicolumn{1}{|c|}{ Hausman Testi } \\
\hline $\boldsymbol{I}(\boldsymbol{A K})$ & $2.26(0.000)$ & $26.76(0.000)$ & $9.34(0.0094)$ \\
\hline $\boldsymbol{I I}(\boldsymbol{O} K \boldsymbol{K})$ & $7.68(0.000)$ & $219.22(0.000)$ & $345.61(0.000)$ \\
\hline $\mathrm{H}_{0}$ : Birim etkiler sıfira eşittir. & $\mathrm{H}_{0}$ : Tesadüfi etkiler geçerlidir. \\
\hline
\end{tabular}

Yapılan F testi ve olabilirlik oranı test sonuçlarına göre verilerin birim etki barındırdığ 1 ve klasik modelin uygun olmadığ 1 sonucuna varılmaktadır. Elde edilen sonuçlara göre klasik modelin uygun olmadığı sabit etkili veya tesadüfi etkili modelin kullanılması gerekmektedir. Bu kapsamda sabit etkiler tahmincisi ile tesadüfi etkiler tahmincisi arasında karar vermek üzere yapılan Hausman testi sonuçlarına göre sabit etkili modelin kullanımının geçerli olduğu sonucuna varılmıştır. Elde edilen tüm sonuçlar sonrasında kurulan sabit etkili modellere ilişkin varsayımların test sonuçları Tablo 6'da yer almaktadır.

Tablo 6. Grup İçi Sabit Etkiler Regresyon Modeli Varsayımları Test Sonuçları

\begin{tabular}{|l|c|r|c|}
\hline Varsayım & Heteroskedasite & Otokorelasyon & Birimler Arası Korelasyon \\
\hline $\begin{array}{r}\text { Test } \\
\text { Mode }\end{array}$ & $\begin{array}{c}\text { Wald Testi } \\
\text { Chi }^{2}(p-\text { value })\end{array}$ & Durbin Watson & $\begin{array}{c}\text { Pesaran'in Testi } \\
\text { Chi }^{2}(p-v a l u e)\end{array}$ \\
\hline $\boldsymbol{I}(\boldsymbol{A K})$ & $320000(0.0000)$ & 1.716233 & $5.560(0.0000)$ \\
\hline $\boldsymbol{I I}(\boldsymbol{O ̈ K K})$ & $6300000(0.0000)$ & 1.5242475 & $1.190(0.2340)$ \\
\hline
\end{tabular}

Sabit etkiler tahmin yöntemi ile test edilen modellere yönelik varsayımların testlerinden, birimlere göre değişen varyans sorunu olarak bilinen heteroskedasite sabit etkili modeller için Wald testi ile sınanmaktadır. Varyansların sabit olduğunu test eden Wald testi sonucunun olasılık değerlerinin 0.05 'ten (p: .0000) küçük olması nedeniyle her iki modelde de değişen varyans sorunu olduğu görülmektedir. Diğer yandan hata terimlerinin 
otokorelasyon sorununu ortaya koyan Durbin Watson (DW) test istatistiği sonuçlarının genel olarak kabul edilen 2 oranının altında olması otokorelasyon sorununa işaret etmektedir. Yapılan test ile çalışmada test edilen her iki modelde de DW test sonucu 2 değerinin altında olması nedeniyle otokorelasyon sorununun olduğu belirlenmiştir. Birimler yani yatay kesitler boyunca hataların eş zamanlı korelasyonlu olması birimler arası korelasyon sorunu olarak anılmaktadır. Birim boyutunun zaman boyutundan çok fazla olması durumunda birimler arası korelasyonun test edilmesinde Pesaran testinin kullanılması önerilmektedir. $\mathrm{H}_{0}$ hipotezi birimler arası korelasyon olmadığ 1 yönünde olup temel hipotezin kabul edilmesi istenen durumdur. Yapılan Pesaran testi sonucuna göre Model I (AK)'de birimler arası korelasyon sorunu var iken, model II (ÖKK)'de birimler arası korelasyon sorunu olmadığı Tablo 6'da görülmektedir.

Kurulan regresyon modellerinde elde edilen sonuçların etkinliğinden söz edebilmek için Tablo 6'da verilen ve daha önce ifade edilen varsayımların sağlanması gerekmektedir. Varsayımların sağlanmaması ya da en azından birinin varlığı halinde varyansların, standart hataların, $t$ ve $F$ istatistiklerinin, $R^{2}$ ve güven aralıklarının geçerliliği etkilenmektedir. $B u$ nedenle değişen varyans, otokorelasyon ve birimlerarası korelasyonun en az birinin varlığ halinde parametrelere dokunmadan dirençli standart hatalar üretilmeli ya da uygun yöntemlerle tahmin edilmelidir (Yerdelen Tatoğlu, 2013b: 240-241).

Model I'de tahmin edilen modelin bütün varsayımları sağlamadığı, ayrıca zaman boyutunun birim boyutu kadar büyük olmadığı durumlarda geçerli olan Driscoll-Kraay tahmincisinin kullanılması önerilmektedir. Bu kapsamda değişen varyans, otokorelasyon ve aynı zamanda birimler arası korelasyon sorunu bulunan aktif kârlılı̆̆ Driscoll-Kraay tahmincisi ile tahmin edilmiş olup, elde edilen sonuçlar Tablo 7'de yer almaktadır.

Elde edilen sonuçlara göre kurulan model $\mathrm{F}$ testi anlamlı olup açıklama oranını ifade eden $\mathrm{R}^{2} \% 29$ düzeyindedir. DuPont analizi tekniği bağlamında AK'nin hesaplanmasında $\mathrm{NKM}$ ve $\mathrm{ADH}$ oranları kullanılmaktadır. Bu kapsamda modelde bağımsız değişkenlerin bağımlı değişken üzerindeki etkisinin anlamlılığını gösteren $t$ istatistik değerine göre ele alınan bu iki orandan NKM'nin AK üzerindeki etkisinin istatistiki açıdan anlamlı ve pozitif yönde, ADH'nin ise istatistiki açıdan anlamsız olduğu görülmektedir. Bu sonuçlara göre NKM'de meydana gelen 1 birimlik oransal değişim, AK'de 0.02 birim oransal bir değişime neden olacaktır. Elde edilen bu sonuca göre otel işletmelerinde AK'deki değişimde etkili olan faktörün NKM olduğu ve işletmelerin aktif kârlılığını arttırmada yalnızca satışları değil, satışlarına karşı elde edecekleri net kârı arttırmalarının yanı sıra maliyet ve gider kontrolüne önem vermeleri gerektiği söylenebilir.

Tablo 7. Aktif Kârlılığını Etkileyen Faktörler (Model I)

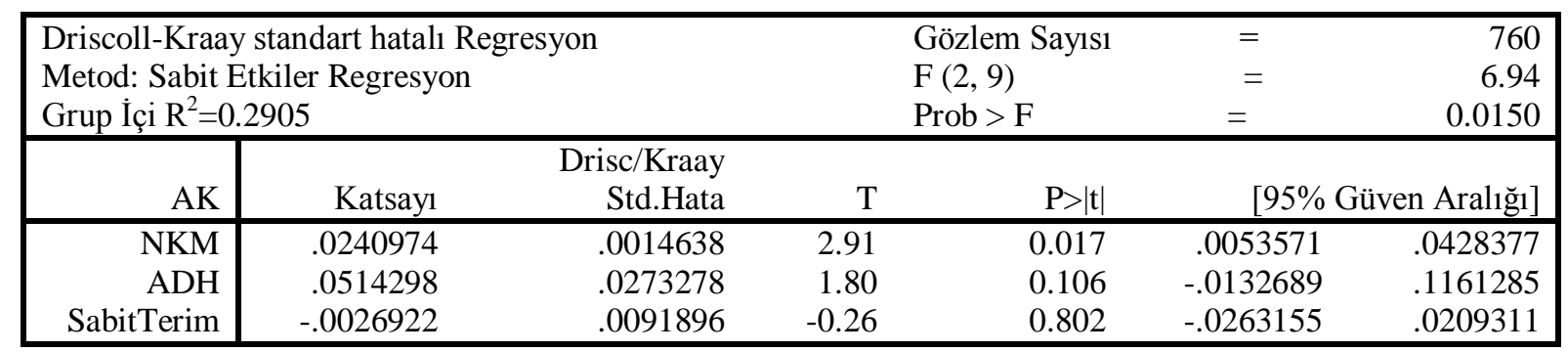


Model II'ye yönelik varsayımlardan değişen varyans ve otokorelasyon sorununun varlığı halinde etkin sonuçların elde edileceği ve dirençli standart hatalar üreten Arellano, Froot ve Rogers tahmincisi ile model tahmin edilmektedir. Bu kapsamda DuPont tekniği kapsamında ele alınan özkaynak kârlılığına etki eden oranların saptanmasına yönelik kurulan regresyon modeline ilişkin sonuçlar Tablo 8'de yer almaktadır.

Tablo 8. Özkaynak Kârlılığını Etkileyen Faktörler (Model II)

\begin{tabular}{|c|c|c|c|c|c|c|}
\hline \multicolumn{3}{|c|}{$\begin{array}{l}\text { Sabit Etkili (Grup İçi) Regresyon } \\
\text { Grup Değiskeni: İsletme }\end{array}$} & \multicolumn{2}{|c|}{ Gözlem Sayısı } & $=$ & $\begin{array}{r}760 \\
76\end{array}$ \\
\hline $\mathrm{R}^{2}: \quad$ Grup & ci $=0.8487$ & & Grupt: & $\mathrm{m}:$ & $=$ & 10 \\
\hline G.aras & $=0.6404$ & & & 75) & $=$ & 560.89 \\
\hline Tüm & $=0.7705$ & & & Prob $>F$ & $\mathrm{~F}$ & 0.0000 \\
\hline ÖKK & Katsayı & $\begin{array}{r}\text { Robust } \\
\text { Std.Hata }\end{array}$ & $\mathrm{t}$ & $P>|t|$ & \multicolumn{2}{|c|}{ [95\% Güven Aralığı $]$} \\
\hline NKM & .0388858 & .0124876 & 3.11 & 0.003 & .0140092 & .0637625 \\
\hline $\mathrm{ADH}$ & .138872 & .0770008 & 1.80 & 0.075 & -.0145215 & .2922655 \\
\hline ÖKÇ & -.1453098 & .0038271 & -37.97 & 0.000 & -.1529338 & -.1376859 \\
\hline Sabit Terim & .2555432 & .0270623 & 9.44 & 0.000 & .2016323 & .3094542 \\
\hline sigma_u & .12384236 & & & & & \\
\hline sigma_e & .12800645 & & & & & \\
\hline rho & .48347046 & & & & & \\
\hline
\end{tabular}

Arellano, Froot ve Rogers dirençli standart hatalar sabit etkili regresyon yöntemiyle elde edilen sonuçlara göre kurulan model, F test istatistiğine göre anlamlı olup modelde yer alan bağımsız değişkenlerin bağımlı değişkendeki değişimleri açıklama oranı olan $\mathrm{R}^{2} \% 85$ dolaylarındadır. DuPont analiz tekniği kapsamında ele alınan oranlardan NKM ve ÖKÇ'nin etkisi istatistiki açıdan \%5 anlamlılık düzeyinde anlamlı iken, ADH'nin etkisi \%5 düzeyinde anlamsız olup, \%10 düzeyinde anlamlıdır. NKM'deki değişimler ÖKK'yi pozitif yönde etkilerken, ÖKÇ'deki değişimler ile ÖKK'nin etkileşimi ters yöndedir. NKM'de meydana gelen 1 birimlik oransal artış/azalış, ÖKK'de 0.038 birimlik oransal artışa/azalışa neden olurken, ÖKÇ'deki 1 birimlik oransal değişim ÖKK'de 0.145 birimlik ters yönlü oransal değişime neden olacaktır. Bu sonuca göre incelenen işletmelerde özkaynak çarpanının artması halinde özkaynak kârlılığının azalacağı buna karşın net kâr marjındaki artış özkaynak kârlılı̆̆ını artırıcı bir unsur olarak karşımıza çıkmaktadır. Söz konusu sonuç detaylı olarak incelendiğinde otel işletmelerinin faaliyetleri sonucunda zarar etmelerinden kaynaklı net kar marjının negatif gerçekleştiği, bu bağlamda finansal kaldıraçtan yararlanma düzeyini gösteren özkaynak çarpanında meydana gelen bir artış, özkaynak kârlılığında azalmaya neden olmaktadır. Buradan hareketle işletmelerin maliyet ve gider kontrolü konularına gereken önemi vererek, vergi avantajı sağlamasının yanında bir maliyet kalemi olan yabancı kaynak kullanımına karşın, özkaynak kullanımını optimal seviyede tutmaları gerekmektedir.

\section{SONUÇ}

İşletmelerde performansın bir ölçütü olarak aktif kârlılığ işletmelerin finansal performansı hakkında bilgiler ortaya koymaktadır. $\mathrm{Bu}$ bağlamda işletmelerin kârlılı̆̆ının ortaya konması ve kârlılı̆̆ı etkileyen unsurların tespiti ve eksikliklerinin saptanması açısından DuPont analizi önem arz etmektedir. Avrupa borsalarında payları işlem gören otel işletmelerinin kârlılıklarının DuPont analiz tekniğinde 
kullanılan oranlar bağlamında incelendiği bu çalışmada yetmiş altı işletmenin 2007-2016 dönemi yıllık verilerinden hareketle aktif ve özkaynak kârlılıklarını etkileyen değişkenler belirlenmeye çalışılmıştır.

Yapılan bu çalışmayla incelenen işletmelerin 760 gözlemden oluşan panel verilerine ilişkin ortalama değerleri bağlamında net kâr marjının negatif, aktif devir hızının yaklaşık 0.33, özkaynak çarpanının ise 2 dolaylarında gerçekleştiği görülmüştür. Diğer yandan aktif kârlılığının ortalama \%1 dolaylarında, özkaynak kârlılığının ise \%-0.2 olduğu görülmüştür. Gerçekleştirilen panel veri regresyon analizi sonucunda halka açık otel işletmelerinde aktif kârlılığında etkili olan unsurun net kâr marjı olduğu saptanmış olup, aktif kârlılığında aktif devir hızının anlamlı bir etkisi saptanamamıştır. Bu sonuç Bauman (2014)'ın çalışması ile uyumluluk göstermektedir. Bu çalışmada aktif devir hızı ile ilgili elde edilen sonuç Karadeniz ve İskenderoğlu (2012)'nun halka açık turizm işletmelerinde gerçekleştirdiği çalışmada çıkan anlamlı pozitif etki gösterdiği şeklindeki sonuç ile uyumsuzdur. Bu bağlamda işletmelerin aktif kârlılığını artırmasında önemli olan etkenin her bir birim satışından elde edeceği net kârın arttırılmasından geçmektedir. Bunu sağlamak içinde otel işletmelerinin maliyet ve giderlerini azaltmaları önem arz etmektedir. Karadeniz ve İskenderoğlu (2012)'nun elde ettikleri sonuçlardan biri olan yüksek kaldıraç kullanımının işletmenin riskini arttırması nedeniyle borç ve özkaynak maliyetini arttırarak ortalama sermaye maliyetini arttıracağ 1 ve bu sonucun işletmenin katlandığı maliyetleri ve net kârı dolayısıyla aktif kârlılığını etkileyeceği belirtilmektedir.

Çalışmada özkaynak kârlılığı üzerinde anlamlı etkisi olan oranların ise net kâr marjı ve özkaynak çarpanı olduğu saptanmıştır. Tarafimızca yapılan bu çalışmada özkaynak kârlılığında net kâr marjının pozitif, özkaynak çarpanının ise negatif bir etkisinin olduğu saptanmıştır. Buna karşın aktif devir hızının özkaynak kârlılığında da etkisinin anlamlı olmadığı saptanmıştır. Bu sonuçlar Warrad ve Nassar (2017)'ın sanayi işletmeleri üzerinde yaptığ 1 çalışma ile kısmi benzerlik ve farklılıklara sahiptir. Net kâr marjının etkisi Warrad ve Nassar (2017)'ın çalışmasında da anlamlı olup, ilgili işletmelerde aktif devir hızının etkisi anlamlı iken, özkaynak çarpanının etkisinin anlamsız olduğu saptanmıştır. Warrad ve Nassar (2017) tarafindan yapılan çalışmada elde edilen bu sonuçlara göre satışlar üzerinden tatmin edici düzeyde kâr elde edildiği ve sahip olunan net kâr marjı düzeyinde satışların arttırılmasının işletmelerin kârlılı̆̆ında olumlu etkilerinin olduğu söylenebilir.

Çalışmamızda elde edilen sonuçlara göre işletmelerin satışlarına karşı net kârını arttırmaları özkaynak kârlılığına pozitif etki edecektir. Ancak işletmelerde net kâr marjının negatif olduğu düzeyde, sermaye yapılarında yabancı kaynak kullanımını artırması sermaye yapısı teorilerinden hareketle vergi kalkanı etkisi yanında aşırı borç kullanımının getirmiş olduğu faiz yükü nedeniyle net kâra dolayısıyla özkaynak kârlılığına ters yönde bir etki ettiğini söylemek mümkündür. Diğer yandan tatmin edici düzeyde sahip olunan net kâr marj1 durumunda, finansal kaldıraçtan yararlanma bağlamında özkaynak çarpanının arttığı ölçüde özkaynak kârlılığı artabilir. Bu kapsamda çalışmamızda payları Avrupa borsalarında işlem gören otel işletmelerinin net kâr ve dolayısıyla net kâr marjının tatmin edici düzeyde gerçekleşmediği söylenebilir.

Otel işletmelerinin önemli bir özelliği olan sabit maliyetlerin yüksek ve sunulan ürünün stoklanamaz özellikte olması nedeniyle, turizm talebinde görülecek olası bir daralma sabit maliyetlerin karşılanmasında sorunlara neden olabilmektedir. Bu kapsamda çalışmada 
elde edilen sonuçlar bağlamında en önemli sonucun işletmelerin yapmış oldukları satı̧̧lara karşın elde edecekleri net kârı arttıracak biçimde maliyet ve gider unsurlarının üzerinde yoğunlaşmaları gerektiğidir. Diğer yandan net kârları üzerinde etkili olacak şekilde maliyet ve gider kontrolü yapmalarının yanı sıra fiyat politikalarını gözden geçirmeleri gerekmektedir. Finansal kaldıraç kullanımı gerek borcun vergi avantajı açısından gerekse özkaynak kârlılığına yapacağı olumlu etki nedeniyle tercih edilen bir durumdur. Çalışmada incelenen işletmelerde borç kullanımının bir avantaj olmaktan öte aşırı borç kullanımı nedeniyle faiz yükümlülüklerinin özkaynak kârlılığını ters yönde etkilediği belirlenmiștir. Bu bağlamda işletmelerin özkaynak kârlılıklarını artırmak istemeleri durumunda, borç kullanım oranlarını optimal sermaye yapısını oluşturacak düzeyde tutmaları gerekmektedir. İstenilen net kar düzeyine ulaşılamaması nedeniyle otel işletmelerinin aşırı borç kullanımından vazgeçmeleri, varlık/kaynak yapısını dikkate alacak şekilde optimal sermaye yapısına ulaşmaları ve bu düzeyi korumaları gerektiği söylenebilir.

DuPont analizi tekniğinin temelinde, incelenen tüm oranların pozitif olması durumunda aktif kârlılığının artması net kâr marjının ve aktif devir hızının artmasından bununla birlikte özkaynak kârlılığının artması tüm oranların artmasından geçmektedir. Bu noktada özkaynak kârlılığında en temel hususun net kârın ve dolayısıyla net kâr marjının pozitif yönde olmasının gerektiği ortaya çıkmaktadır.

Çalışma sonucunda elde edilen bulguların halka açı oteli işletmelerine yönelik literatürdeki eksikliği gidermesinin yanı sıra sektördeki işletmelerin finans ve muhasebe yöneticilerine fikir sunması ve eksikliklerini gidermeleri bağlamında katkı sağlayacağı düşünülmektedir. Çalışma otel işletmelerinin kârllıklarında DuPont tekniğinin uygulanarak aktif kârllı̆ğı ve özkaynak kârlllığında etkili olan oranların ortaya konması açısından önem arz etmekle birlikte ilgili kalemlerin alt unsurlarının ele alınarak detaylı incelenmemesi çalışmanın sınırlılıklarındandır. Diğer yandan DuPont analiz tekniği kapsamında ele alınan oranlar dışında diğer işletme içi ve makroekonomik değişkenlerin etkisinin incelenmemiş olması çalışmanın diğer bir kısıtıdır. Bu kısıt ve sınırlılıklar kapsamında gelecek çalışmalarda otel işletmelerinin aktif ve özkaynak kârlılıklarında DuPont tekniği bağlamında ele alınan değişkenlerin alt unsurlarını kapsayan değişkenlerin ve diğer işletme içi ve makro değişkenlerin ele alınarak ampirik çalışmaların yapılması önerilebilir.

\section{KAYNAKLAR}

Aydın, Nurhan - Başar, Mehmet - Coşkun, Metin (2007), Finansal Yönetim, 2. Baskı. Genç Copy Center, Eskişehir.

Baltagi, Badi H. (2005), Econometric Analysis of Panel Data, 3. Edt., John Wiley \& Sons Ltd, England.

Bauman, Mark P. (2014), "Forecasting Operating Profitability with DuPont Analysis: Further Evidence", Review of Accounting and Finance, 13, 2, pp. 191-205.

Botika, Marianna (2012), "The Use of DuPont Analysis in Abnormal Returns Evaluation: Empirical Study of Romanian Market”, Procedia-Social and Behavioral Sciences, 62, pp. 1179-1183. 
Doğan, Mesut- Topal, Yusuf (2016), “Kârlılı̆̆ı Belirleyen Finansal Faktörler: BIST’te İşlem Gören İmalat Sanayi Firmaları Üzerine Bir Araştırma", Optimum Ekonomi ve Yönetim Bilimleri Dergisi, 3 (1), ss.53-64.

Guilding, Chris (2002), Financial Management for Hospitality Decision Makers, ButterworthHeinemann, Oxford.

Harris, Richard D. F. - Tzavalis, Elias (1999), "Inference for Unit Roots in Dynamic Panels where the Time Dimension is Fixed", Journal of Econometrics, 91, pp. 201-226.

Hausman, J. A. (1978), “Specification Tests in Econometrics”, Econometrica, 46, 6,pp.12511271.

Kaplan, Fatih (2016), Ekonomik Büyüme Dolaylı Belirleyicileri ve Bir Uygulama, Savaş Yayınevi, Ankara.

Karadeniz, Erdinç - Kandır, Serkan Yılmaz - Balcılar, Mehmet - Önal, Yıldırım Beyazıt. (2009), "Determinants of Capital Structure: Evidence from Turkish Lodging Companies", International Journal of Contemporary Hospitality Management, 21, 5, pp. 594-609.

Karadeniz, Erdinç -İskenderoğlu, Ömer (2012), “İstanbul Menkul Kıymetler Borsası'nda İşlem Gören Turizm İşletmelerinin Aktif Kârlılığını Etkileyen Değişkenlerin Analizi”, Anatolia: Turizm Araştırmaları Dergisi, 22, 1, ss. 65-75.

Karadeniz, Erdinç - Kaplan, Fatih - Günay, Fatih (2016), "Sermaye Yapısı Kararlarının Kârlılığa Etkisi: Borsa İstanbul Turizm Şirketlerinde Bir Araştırma", Seyahat ve Otel İşletmeciliği Dergisi, 13, 3, ss. 38-55.

Karaman, Süleyman- Özalp, Asaf- Yılmaz, İbrahim (2014), Tarımsal Kalkınma Kooperatif Kârlılığının DuPont Model Analizi, Ulusal Aile Çiftliği Sempozyumu, 30-31 Ekim 2014, Ankara.

Karapınar, Aydın - Ayıkoğlu Zaif, Figen (2013), Finansal Analiz, Gazi Kitabevi, Ankara.

Koşan, Levent - Karadeniz, Erdinç (2013), “Türk İmalat Sektöründe Küçük, Orta ve Büyük Ölçekli İşletmelerin Finansal Performansının Dupont Analiz Tekniğiyle İncelenmesi”, Çağ Üniversitesi Sosyal Bilimler Dergisi, 10, 2, ss. 45-62.

Koşan, Levent - Karadeniz, Erdinç (2014), "Konaklama ve Yiyecek Hizmetleri Alt Sektörünün Finansal Performansinın DuPont Finansal Analiz Sistemi Kullanılarak İncelenmesi”, Seyahat ve Otel İşletmeciliği Dergisi, 11, 2, ss. 75-89.

Kim, Hak-Seon (2016), “A Study of Financial Performance Using DuPont Analysis in Food Distribution Market”, Culinary Science \& Hospitality Research, 22, 6, pp. 52-60.

Sheela, S. Christina - Karthikeyan, K. (2012), "Financial Performance of Pharmaceutical Industry in India Using DuPont Analysis", European Journal of Business and Management, 4, 14, pp. 84-91. 
Turner, Jason - Broom, Kevin - Elliott, Micheal - Lee, Jen-Fu (2015), “A Decomposition of Hospital Profitability: An Application of DuPont Analysis to the US Market", Health Services Research and Managerial Epidemology, pp. 1-10.

Warrad, Lina Hani - Nassar, Mahmoud (2017), "Could Profitability, Activity and Use of Equity Finance Increasing DuPont Model of Return on Equity? Jordanian Case", International Review of Management and Marketing, 7, 3, pp. 35-41.

Wooldridge, Jeffrey M. (2002), Econometric Analysis of Cross Section and Panel Data, The MIT Press, Cambridge Massachusetts, London.

Yerdelen Tatoğlu, Ferda (2013a), İleri Panel Veri Analizi (Stata Uygulamalı), 2. Baskı, Beta Basım Yayım Dağıtım, İstanbul.

Yerdelen Tatoğlu, Ferda (2013b), Panel Veri Ekonometrisi (Stata Uygulamal1), 2. Baskı, Beta Basım Yayım Dağıtım, İstanbul. 